\title{
The Influence Of Debt To Equity Ratio (DER) And Net Profit Margin (NPM) To Changes In Earnings In Construction And Building Sub-Sector Companies Listed In Indonesia Stock Exchange 2016-2019
}

\author{
Kiki Tri Rizky ${ }^{a, 1, *}$, Fika Aryani ${ }^{b, 2}$ \\ a,b Institut Ilmu Sosial dan Manajemen STIAMI \\ ${ }^{1}$ kikitririzky280298@gmail.com *; ${ }^{2}$ aryanifika@gmail.com \\ * corresponding author
}

\section{ARTICLE INFO}

Article History

Received, 15-Okt-2020

Reviewed, 23-Okt-2020

Published, 31-Okt-2020

Keywords

Debt To Equity Ratio;

Net Profit Margin;

Profit Change;

Construction and building

sub-sector companies.

\section{ABSTRACT}

This study aims to examine and analyze the influence of Debt To Equity Ratio(DER) and Net Profit Margin (NPM) to changes in Earnings in Construction and Building Sub-Sector Companies listed in Indonesia Stock Exchange 2016-2019. A sample of 40 data were obtained using purposive sampling method. This research used a quantitative approach with associative research type. Data analysis method used is multiple linear regression method.The results show that partially the Debt To Equity Ratio has a statistically significant negative effect to change in Earnings, this is indicated by the results of the t test for the variable DER -15.149> 2.026 and Net Profit Margin. statistically significant effect to changes in Earnings as indicated by the $t$ test for the variable NPM 5,753> 2,026. Simultaneously, Debt to Equity Ratio and Net Profit Margin have a significant effect simultaneously to changes in Earnings, this is indicated by the significance of the $F$ test of $0.000<0.05$.

\section{PENDAHULUAN}

\section{Latar Belakang}

Perkembangan suatu negara tidak terlepas dari adanya perubahan dan perbaikan infrastruktur di negara tersebut. Dalam hal ini Indonesia yang masih dikategorikan dalam status negara berkembang di berbagai belahan dunia masih akan terus melakukan pembenahan dari sarana maupun prasarana infrastruktur yang ada. Hal ini pula yang mendasari berbagai perusahaan emiten sektor konstruksi dan bangunan seakan berlomba-lomba untuk mendapatkan proyek kontrak tersebut. Pada umumnya suatu perusahaan dibangun dengan tujuan untuk memperoleh laba. Menurut Samryn (2012:429) laba merupakan sumber dana internal yang dapat diperoleh dari aktivitas normal perusahaan yang tidak membutuhkan biaya ekstra untuk penyimpanan dan penggunaannya.

Penelitian yang dilakukan oleh Riduan dan Budiharjo (2019) pada Perusahaan Jasa Perhotelan yang terdaftar di Bursa Efek Indonesia menunjukkan bahwa Net Profit Margin (NPM) berpengaruh signifikan terhadap perubahan laba. Sejalan dengan peneltian yang dilakukan oleh Nugraha (2017) bahwa Net Profit Margin berpengaruh signifikan dengan perubahan laba. Berbeda dengan penelitian yang dilakukan oleh Arlinia dan Subekti (2017) bahwa NPM tidak berpengaruh pada perubahan peningkatan dan penurunan laba sehingga rasio likuiditas ini tidak berpengaruh terhadap perubahan laba perusahaan perikanan. Menurut Utari, Ari dan Darsono (2014:67), menyatakan bahwa pertumbuhan laba perusahaan yang baik mencerminkan bahwa kondisi kinerja perusahaan juga baik, jika kondisi ekonomi baik pada umumnya pertumbuhan perusahaan juga baik.

Seperti penelitian yang dilakukan oleh Rohmatin (2017) dengan menggunakan metode analisis regresi berganda untuk menganalisis pengaruh DER, TATO, GPM, dan ROE terhadap perubahan laba. Hasil yang diperoleh adalah Debt To Equity Ratio (DER) tidak berpengaruh signifikan secara parsial terhadap perubahan laba. Hasil perhitungan diperoleh nilai profabilitas sebesar 0,257 . Nilai 
signifikasi lebih besar dari 0,05 , berarti bahwa DER tidak memiliki pengaruh yang signifikan terhadap perubahan laba. Hasil penelitian Rohmatin (2017) sejalan dengan penelitian yang dilakukan Nugraha (2017) yaitu DER tidak berpengaruh signifikan terhadap perubahan laba. Berbeda dengan penelitian Mas'ulah dan Budiyanto (2016) dengan menggunakan metode analisis regresi berganda untuk menganalisis pengaruh CR, DER, TATO, dan NPM terhadap perubahan laba. Hasil yang diperoleh adalah CR dan TATO berpengaruh tidak signifikan terhadap perubahan laba. Sedangkan, DER dan NPM berpengaruh signifikan terhadap perubahan laba. Berdasarkan penelitian tersebut maka, peneliti melakukan pengujian kembali atas Debt To Equity Ratio (DER) terhadap perubahan laba untuk membuktikan kembali hasil penelitian terhadap variabel tersebut apakah menjadi signifikan atau tidak signifikan.

Dalam penelitian ini rasio yang digunakan adalah rasio solvabilitas dengan Debt To Equity Ratio (DER) dan rasio profitabilitas dengan Net Profit Margin (NPM). Tabel 1 merupakan data laba bersih perusahaan konstruksi dan bangunan yang terdaftar di Bursa Efek Indonesia periode $2016-2019$.

Tabel 1. Laba Bersih Perusahaan Kontruksi dan Bangunan di Bursa Efek Indonesia Periode 2016 - 2019

\begin{tabular}{|c|c|c|c|c|}
\hline \multirow[t]{2}{*}{$\begin{array}{l}\text { Kode } \\
\text { Saham }\end{array}$} & \multicolumn{4}{|c|}{ Laba/Rugi Bersih (Rupiah) } \\
\hline & 2016 & 2017 & 2018 & 2019 \\
\hline ACST & $67,555,000,000$ & $153,791,000,000$ & $21,419,000,000$ & $(1,131,849,000,000)$ \\
\hline ADHI & $315,107,783,135$ & $517,059,848,207$ & $645,029,449,105$ & $665,048,421,529$ \\
\hline IDPR & $120,413,914,040$ & $114,258,186,025$ & $31,180,315,557$ & $(3,509,738,431)$ \\
\hline NRCA & $101,091,266,970$ & $153,443,549,305$ & $117,967,950,221$ & $101,155,011,546$ \\
\hline РTPP & $1,148,476,320,716$ & $1,723,852,894,286$ & $1,958,993,059,360$ & $1,208,270,555,330$ \\
\hline SSIA & $100,854,847,637$ & $1,241,357,001,429$ & $89,833,255,584$ & $136,311,060,539$ \\
\hline TOTL & $221,287,384,000$ & $231,269,085,000$ & $204,418,079,000$ & $175,502,010,000$ \\
\hline WEGE & $143,226,486,832$ & $295,745,800,040$ & $444,498,792,703$ & $456,366,738,475$ \\
\hline WIKA & $1,211,029,310,000$ & $1,356,115,489,000$ & $2,073,299,864,000$ & $2,621,015,140,000$ \\
\hline WSKT & $1,813,068,616,784$ & $4,201,572,490,754$ & $4,619,567,705,553$ & $1,028,898,367,891$ \\
\hline
\end{tabular}

(Sumber : www.idx.co.id)

Berdasarkan tabel diatas perusahaan BUMN yang bergerak di sub sektor Kontruksi dan Bangunan seperti PT Adhi Karya (Persero) Tbk dengan kode saham ADHI. membukukan pertumbuhan laba bersih setiap tahunnya. Sama halnya dengan perusahaan BUMN kode emiten PTPP, WEGE dan WIKA mengalami kenaikan laba setiap tahunnya. Sedangkan perusahaan swasta konstruksi dan bangunan lainnya seperti PT. Total Bangun Persada Tbk (TOTL), PT Acset Indonusa Tbk (ACST), dll mengalami kenaikan dan penurunan laba yang berfluktuatif setiap tahunnya.

Beberapa penelitian masih menunjukan hasil yang berbeda. Bahkan bertentangan dari hasil penelitian satu dengan penelitian yang lainnya. Sehingga berdasarkan latar belakang diatas, peneliti sangat tertarik untuk melakukan penelitian yang berjudul "Pengaruh Debt To Equity Ratio Dan Net Profit Margin Terhadap Perubahan Laba Pada Perusahaan Sub Sektor Konstruksi Dan Bangunan yang Terdaftar di Bursa Efek Indonesia Periode 2016-2019”. 


\section{Ruang Lingkup Penelitian}

Penelitian ini hanya akan mengkaji tentang pengaruh Debt To Equity Ratio (DER) dan Net Profit Margin (NPM) terhadap Perubahan Laba pada Perusahaan Konstruksi yang terdaftar di Bursa Efek Indonesia periode tahun 2016 sampai dengan tahun 2019.

\section{Perumusan Masalah}

Berdasarkan latar belakang yang telah diuraikan maka rumusan masalah dalam penelitian ini yaitu :

1. Seberapa besar Debt To Equity Ratio berpengaruh secara parsial terhadap perubahan laba pada perusahaan Sub Sektor Konstruksi dan Bangunan?

2. Seberapa besar Net Profit Margin berpengaruh secara parsial terhadap perubahan laba pada perusahaan Sub Sektor Konstruksi dan Bangunan?

3. Seberapa besar Debt To Equity Ratio dan Net Profit Margin berpengaruh secara simultan terhadap perubahan laba pada perusahaan Sub Sektor Konstruksi dan Bangunan?

\section{Tujuan Penelitian}

Sesuai dengan perumusan masalah diatas, maka tujuan dari penelitian ini adalah:

1. Untuk mengetahui dan menganalisis seberapa besar pengaruh Debt To Equity Ratio terhadap perubahan laba pada perusahaan Sub Sektor Konstruksi dan Bangunan yang terdaftar di Bursa Efek Indonesia tahun 2016-2019

2. Untuk mengetahui dan menganalisis seberapa besar pengaruh Net Profit Margin terhadap perubahan laba pada perusahaan Sub Sektor Konstruksi dan Bangunan yang terdaftar di Bursa Efek Indonesia tahun 2016-2019.

3. Untuk mengetahui dan menganalisis seberapa besar pengaruh Debt To Equity Ratio dan Net Profit Margin secara simultan terhadap perubahan laba pada perusahaan Sub Sektor Konstruksi dan Bangunan yang terdaftar di Bursa Efek Indonesia tahun 2016-2019.

\section{Manfaat Penelitian}

1. Aspek Akademik

Hasil penelitian ini diharapkan dapat memberikan gagasan baru bagi penelitian selanjutnya. Dan dapat memberikan kontribusi untuk pengembangan ilmu pengetahuan dengan adanya variabel-variabel yang mempengaruhi perubahan laba perusahaan diantaranya Debt To Equity Ratio dan Net Profit Margin.

2. Aspek Praktis

Hasil penelitian ini diharapkan dapat memberikan masukan tambahan informasi mengenai Debt To Equity Ratio dan Net Profit Margin terhadap perubahan laba perusahaan. Sehingga dapat dijadikan acuan bagi perusahaan Sub Sektor Kontruksi dan Bangunan dalam pencapaian laba karena laba yang meningkat mengindikasikan kinerja keuangan perusahaan yang baik.

3. Aspek Kebijakan

Penelitian ini diharapkan dapat memberikan informasi mengenai faktor-faktor yang berkaitan dengan perubahan laba pada perusahaan Kenaikan dan penurunan laba dapat memberikan sinyal kepada para investor dalam memberikan keputusan investasi dan menilai kinerja keuangan perusahaan.

\section{KAJIAN LITERATUR}

\section{Debt To Equity Ratio (DER) (X1)}

Menurut Kasmir (2014) Debt To Equity Ratio (DER) adalah rasio keuangan yang dipakai untuk menilai utang dengan ekuitas perusahaan. Rasio ini digunakan untuk mengetahui total dana yang disediakan oleh peminjam (kreditur) dengan pemilik perusahaan. Dengan kata lain, seberapa besar nilai setiap rupiah modal perusahaan yang dijadikan sebagai jaminan uang. Maka dapat disimpulkan bahwa Debt To Equity Ratio (DER) adalah hasil perbandingan antara total utang perusahaan dengan total ekuitas yang dimilikinya. Debt To Equity Ratio (DER) juga salah satu 
rasio leverage yang dalam pengukurannya dipakai untuk menilai seberapa besar modal perusahaan dibiayai oleh utang.

Menurut Kasmir (2016:157) Debt To Equity Ratio (DER) dapat dirumuskan sebagi berikut:

$$
D E R=\frac{\text { Total Kewajiban }}{\text { Total Ekuitas }}
$$

\section{Net Profit Margin (NPM) (X2)}

Margin laba bersih merupakan ukuran keuntungan dengan membandingkan antara laba bersih setelah bunga dan pajak dibandingkan dengan penjualan. Rasio ini menunjukan pendapatan bersih perusahaan atas penjualan (Kasmir, 2017:200) . Menurut Hanafi dan Halim (2016:81) rasio ini bisa dilihat secara langsung pada analisis common size untuk laporan laba rugi. Rasio ini bisa diinterprestasikan juga sebagai kemampuan perusahaan menekan biaya-biaya (ukuran efisiensi) diperusahaan pada periode tertentu.

Menurut Kasmir (2014:137) Net profit Margin (NPM) dapat dirumuskan sebagai berikut :

$$
N P M=\frac{\text { Laba Bersih }}{\text { Penjualan }}
$$

\section{Perubahan Laba (Y)}

Menurut I Nyoman Kusuma (2012:249) perubahan laba dipengaruhi oleh komponenkomponen dalam laporam keuangan. Perubahan laba yang disebabkan oleh perubahan komponen laporan keuangan misalnya perubahan penjualan, perubahan harga pokok penjualan, perubahan beban operasi, perubahan beban bunga, perubahan pajak penghasilan. Perubahan laba dihitung dengan cara mengurangkan laba bersih tahun ini dengan laba bersih tahun lalu kemudian dibagi dengan laba bersih tahun lalu. Laba yang dimaksud dalam penelitian ini adalah laba EAT (Earning After (ax) yaitu laba bersih setelah pajak.

Menurut Harahap (2015:310) perubahan laba dirumuskan sebagai berikut :

$$
Y=\frac{Y \mathrm{t}-\mathrm{Yt}-1}{Y t-1} \times 100 \%
$$

Keterangan :

$$
\begin{array}{ll}
\mathrm{Y} & =\text { Pertumbuhan Laba } \\
\mathrm{Yt} & =\text { Laba setelah pajak periode tertentu } \\
\mathrm{Yt}-1 & =\text { Laba setelah pajak pada periode sebelumnya }
\end{array}
$$

\section{Kerangka Pemikiran}

Berdasarkan uraian diatas maka kerangka pemikiran penelitian ini dapat di gambarkan sebagai berikut :

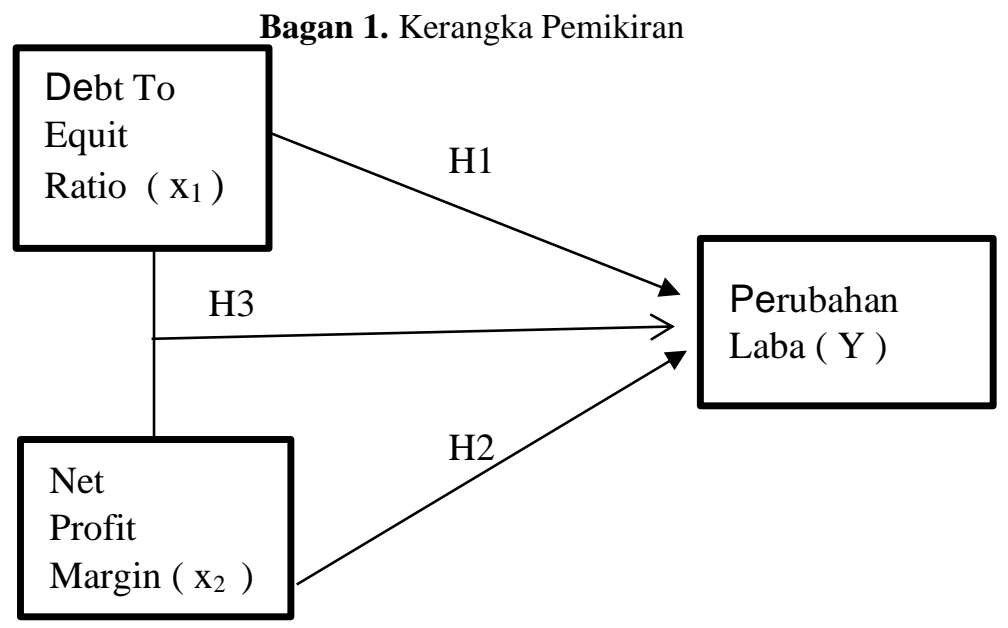




\section{Hipotesis Penelitian}

Berdasarkan kajian literatur dan kerangka pemikiran diatas, maka dapat dirumuskan hipotesis penelitian sebagai berikut :

H1 : Debt To Equity Ratio berpengaruh terhadap Perubahan Laba.

H2 : Net Profit Margin berpengaruh terhadap Perubahan Laba.

H3 : Debt To Equity Ratio (DER) dan Net Profit Margin (NPM) berpengaruh secara simultan terhadap Perubahan Laba.

\section{METODE PENELITIAN}

\section{Pendekatan Penelitian}

Penelitian ini dilakukan dengan menggunakan pendekatan kuantitatif. Penelitian yang dilakukan secara kuantitatif dengan data-data yang tersedia bertujuan untuk menguji pengaruh $D e b t$ To Equity Ratio (DER) dan Net Profit Margin (NPM) terhadap Perubahan Laba, terdapat hubungan yang signifikan atau tidak signifikan dan untuk menguji hipotesa yang diajukan diterima atau ditolak. Berdasarkan tingkat ekplanasinya, penelitian ini dikategorikan sebagai penelitian asosiatif. Penelitian asosiatif adalah penelitian yang bertujuan untuk mengetahui pengaruh ataupun hubungan antara dua variabel atau lebih (Sugiyono, 2012:11).

\section{Teknik Pengumpulan Data}

Data yang digunakan pada penelitian ini yaitu data sekunder. Data sekunder merupakan data tidak langsung memberikan data kepada pengumpulan data. Sumber data yang digunakan dalam penelitian ini adalah dari berbagai sumber buku, laporan keuangan, dan jurnal penelitian terdahulu yang dapat mendukung penelitian ini. Sedangkan untuk sumber data yang akan diolah dalam analisis penelitian adalah dari situs web resmi Bursa Efek Indonesia www.idx.co.id .

\section{Teknik Sampling}

Populasi dalam penelitian ini adalah perusahaan sub sektor konstruksi yang terdaftar di Bursa Efek Indonesia tahun 2016-2019 sebanyak 10 perusahaan. Metode pengambilan sampel yang digunakan adalah menggunakan teknik Purposive Sampling karena kriteria tidak semua sampel memiliki yang sesuai dengan fenomena yang diteliti.

Kriteria sampel tersebut meliputi:

1. Perusahaan sub sektor konstruksi dan bangunan yang memiliki data laporan keuangan tahunan secara lengkap, selama periode 2016 sampai dengan 2019.

2. Perusahaan sub sektor konstruksi dan bangunan yang masih beroperasi selama periode pengamatan dari tahun 2016 sampai dengan 2019.

3. Perusahaan tidak delisting selama periode tahun 2016 sampai dengan 2019.

Adapun perusahaan-perusahaan yang menjadi sampel peneltian disajikan pada tabel berikut ini:

Tabel 2.Daftar Sampel Perusahaan Sektor Konstruksi tahun 2016-2019

\begin{tabular}{|c|l|l|}
\hline No & $\begin{array}{c}\text { Kode } \\
\text { Saham }\end{array}$ & Nama Perusahaan \\
\hline 1 & ACST & PT. Acset Indonusa Tbk \\
\hline 2 & ADHI & PT. Adhi Karya (Persero) Tbk \\
\hline 3 & IDPR & PT. Indonesia Pondasi Raya Tbk \\
\hline 4 & NRCA & PT. Nusa Raya Cipta Tbk \\
\hline 5 & PTPP & PT. Pembangunan Perumahan (Persero) Tbk \\
\hline 6 & SSIA & PT. Surya Semesta Internusa Tbk \\
\hline 7 & TOTL & PT. Total Bangun Persada Tbk \\
\hline 8 & WEGE & PT. Wijaya Karya Bangunan Gedung Tbk \\
\hline 9 & WIKA & PT. Wijaya Karya (Persero) Tbk \\
\hline 10 & WSKT & PT. Waskita Karya (Persero) Tbk \\
\hline
\end{tabular}

Sumber : $\underline{\text { www.idnfinancials.com }}$ 
Jumlah data yang diolah dalam penelitian ini adalah hasil kali perkalian antara jumlah perusahaan sebanyak 10 perusahaan dengan jumlah periode pengamatan, yaitu selama 4 periode (Tahun 2016-2019). Sehingga jumlah pengamatan dalam penelitian ini untuk perusahaan sub sektor konstruksi dan bangunan terdiri dari 40 data observasi.

\section{Variabel Penelitian}

Dalam penelitian ini ada dua variabel yang digunakan yaitu variabel bebas atau variabel independen dan variabel terikat atau variabel dependen. Sehingga dalam penelitian ini yang termasuk variabel independen adalah Debt To Equity Ratio (DER) dan Net profit Margin (NPM), sedangkan variabel dependen adalah Perubahan Laba.

\section{Teknik Analisis Data}

Dalam penelitian ini proses analisis data menggunakan teknik statistik dengan program SPSS versi 24 , metode analisis yang digunakan untuk menguji hipotesis dalam penelitian ini adalah regresi linear berganda dan statistik deskripstif untuk menggambarkan variabel-variabel dalam penelitian ini. Regresi linier berganda dapat dilakukan apabila model penelitian memenuhi syarat dari uji asumsi klasik yaitu uji normalitas, uji multikolinearitas, uji heteroskedastisitas, uji autokorelasi.

\section{HASIL PENELITIAN DAN PEMBAHASAN}

\section{Hasil Penelitian}

\section{Analisis Statistik Deskriptif}

Pada bagian ini akan digambarkan atau dideskripsikan dari data masing-masing variabel yang telah diolah menggunakan SPSS versi 24, adapun hasil olahan data SPSS dalam bentuk deskriptif statistik akan menampilkan karakteristik sampel yang digunakan didalam penelitian antara lain meliputi : jumlah sampel $(\mathrm{N})$, rata-rata sampel (mean), minimum dan maksimum serta standar deviasi (б) untuk masing-masing variabel, yang disajikan dalam Tabel berikut :

Tabel 3

Descriptive Statistics

\begin{tabular}{|c|c|c|c|c|c|}
\hline & $\mathrm{N}$ & Minimum & Maximum & Mean & Std. Deviation \\
\hline DER & 40 & .11 & 35.47 & 2.7288 & 5.44288 \\
\hline NPM & 40 & -28.67 & 37.91 & 5.8805 & 8.02659 \\
\hline PL & 40 & -5384.32 & 1130.84 & -98.5105 & 877.26825 \\
\hline Valid N (listwise) & 40 & & & & \\
\hline
\end{tabular}

Sumber: Output SPSS 24

Berdasarkan tabel deskriptif statistik diatas dapat disimpulkan bahwa nilai mean variabel DER, NPM dan Perubahan Laba lebih kecil dari standar deviasi memiliki arti bahwa perputaran keuangan di perusahaan baik dari segi kemampuan membayar utang, kemampuan penekanan pengeluaran biaya perusahaan untuk menghasilkan laba bersih yang didapat menurun karena laba tersebut digunakan perusahaan untuk memenuhi kewajiban membayar utang dan membayar biayabiaya yang terjadi. 


\section{Uji Asumsi Klasik}

Tabel 4 One-Sample Kolmogorov-Smirnov

Test

\begin{tabular}{|ll|l|}
\hline & & $\begin{array}{l}\text { Unstandardi } \\
\text { zed } \\
\text { Residual }\end{array}$ \\
\hline $\mathrm{N}$ & & 40 \\
Normal & Mean & .0000000 \\
Parameters ${ }^{\mathrm{a}, \mathrm{b}}$ & $\quad$ Std. & 187.401938 \\
& $\quad$ Deviation & 54 \\
Most & ExtremeAbsolute & .124 \\
Differences & Positive & .124 \\
& $\quad$ Negative & -.064 \\
Test Statistic & & .124 \\
Asymp. Sig. (2-tailed) & $.123^{\mathrm{c}}$ \\
\hline
\end{tabular}

a. Test distribution is Normal.

b. Calculated from data.

c. Lilliefors Significance Correction.

Uji asumsi klasik bertujuan untuk meyakinkan bahwa persamaan garis regresi yang diperoleh adalah linier dan dapat dipergunakan untuk mencari peramalan, maka akan dilakukan pengujian asumsi normalitas, multikolonieritas, heteroskedastisitas, dan uji autokorelasi.

\section{a. Uji Normalitas}

Pengujian normalitas data dalam penelitian ini menggunakan uji statistik non parametrik Kolmogorov-Smirnov (K-S) dengan membuat hipotesis:

HO : Data residual berdistribusi normal

H1 : Data residual tidak berdistribusi normal

Apabila nilai signifikannya lebih besar dari 0,05 maka H0 diterima, sedangkan jika nilai signifikansinya lebih kecil dari 0,05 maka H0 ditolak.

Berdasarkan tabel hasil Output SPSS diatas, diketahui bahwa nilai signifikansi Asymp. Sig. (2tailed) sebesar 0,123 berarti $0.123>0.05$. Maka $\mathrm{HO}$ diterima, dapat disimpulkan bahwa $\mathrm{H} 0$ diterima dan data berdistribusi normal serta model regresi dapat digunakan sebagai pengujian berikutnya.

\section{b. Uji Multikolinearitas}

Dalam penelitian ini, untuk mendeteksi ada tidaknya gejala multikolinearitas adalah dengan melihat nilai tolerance dan variance inflation factor (VIF), menganalisis matrik korelasi variabel-variabel independen. Besarnya tingkat kolinearitas yang masih dapat ditolerir yaitu : Tolerance $>0.10$; Variance Inflation Factor $($ VIF $)<10$. Berikut disajikan tabel hasil pengujian.

Tabel 5. Coefficients ${ }^{\mathrm{a}}$

\begin{tabular}{|c|c|c|c|c|c|c|c|}
\hline \multirow[b]{2}{*}{ Model } & \multicolumn{2}{|c|}{$\begin{array}{l}\text { Unstandardi } \\
\text { zed Coefficients }\end{array}$} & \multirow{2}{*}{\begin{tabular}{|l|} 
Standardized \\
Coefficients \\
Beta \\
\end{tabular}} & \multirow[b]{2}{*}{$\mathrm{T}$} & \multirow[b]{2}{*}{ Sig. } & \multicolumn{2}{|c|}{\begin{tabular}{|l} 
Collinearity \\
Statistics
\end{tabular}} \\
\hline & $\mathrm{B}$ & Std. Error & & & & Tolerance & VIF \\
\hline 1 (Constant) & 48.935 & 58.436 & & .837 & .408 & & \\
\hline DER & -121.411 & 8.015 & -.753 & -15.149 & .000 & .499 & 2.005 \\
\hline NPM & 31.265 & 5.435 & .286 & 5.753 & .000 & .499 & 2.005 \\
\hline
\end{tabular}

a. Dependent Variable: PL

Hasil perhitungan nilai tolerance menunjukkan variabel independen memiliki nilai tolerance > 0.10 yaitu 0,499 untuk Debt to Equity Ratio dan nilai tolerance sebesar 0,499 untuk Net Profit Margin. Hasil perhitungan VIF juga menunjukkan hal yang sama dimana variabel independen 
memiliki nilai VIF kurang dari 10 yaitu sebesar 2.005. Hal tersebut menunjukkan tidak terjadi multikolinearitas, sehingga model ini layak digunakan untuk analisis selanjutnya

\section{c. Uji Heteroskedastisitas}

Tabel 6 Coefficients ${ }^{\mathrm{a}}$

\begin{tabular}{|c|c|c|c|c|c|c|}
\hline \multirow{2}{*}{\multicolumn{2}{|c|}{ Model }} & \multicolumn{2}{|c|}{ Unstandardized Coefficients } & \multirow{2}{*}{\begin{tabular}{|l} 
Standardized \\
Coefficients \\
Beta
\end{tabular}} & \multirow[b]{2}{*}{$\mathrm{T}$} & \multirow[b]{2}{*}{ Sig. } \\
\hline & & $\mathrm{B}$ & Std. Error & & & \\
\hline \multirow[t]{3}{*}{1} & (Constant) & 144.807 & 38.619 & & 3.750 & .001 \\
\hline & DER & 1.918 & 5.297 & .082 & .362 & .719 \\
\hline & NPM & -2.346 & 3.592 & -.148 & -.653 & .518 \\
\hline
\end{tabular}

a. Dependent Variable: Abs_RES

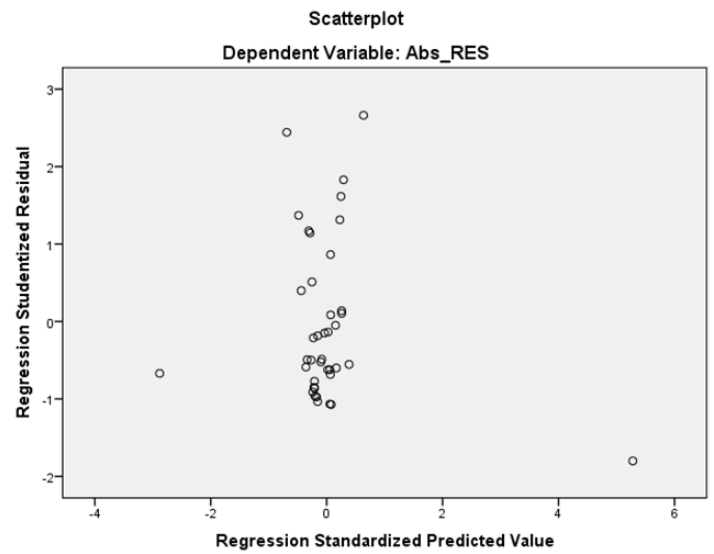

Berdasarkan hasil data diatas menunjukkan bahwa tidak ada variabel independen yang signifikan mempengaruhi variabel dependen dengan nilai absolut. Hal ini terlihat dari nilai signifikansi setiap variabel independen yaitu diatas 0,05 . Jadi dapat disimpulkan model regresi tidak mengandung adanya heterokedastisitas.

\section{d. Uji Autokorelasi}

Tabel 7 Model Summary ${ }^{\mathrm{b}}$

\begin{tabular}{|l|l|l|l|l|l|}
\hline Model & R & R Square & $\begin{array}{l}\text { Adjusted } \\
\text { Square }\end{array}$ & $\begin{array}{l}\text { R } \\
\text { Std. Error of the } \\
\text { Estimate }\end{array}$ & Durbin-Watson \\
\hline 1 & $.977^{\mathrm{a}}$ & .954 & .952 & 192.40020 & 1.643 \\
\hline
\end{tabular}

a. Predictors: (Constant), NPM, DER

b. Dependent Variable: PL

Dari tabel di atas dapat diketahui bahwa nilai DW sebesar 1,643. Nilai ini akan dibandingkan dengan nilai tabel Durbin Watson d Statistic: Significance Points for $\mathrm{dl}$ and $\mathrm{du}$ at 0.05 Level of Significance dengan menggunakan nilai signifikansi 5\%, jumlah sampel $40(\mathrm{n}=40)$ dan jumlah variabel independen $2(\mathrm{k}=2)$, maka dari tabel Durbin-Watson diperoleh nilai batas bawah (dl) sebesar 1.3908 dan nilai batas atas (du) sebesar 1.6000. Nilai DW yaitu 1.643 lebih besar dari batas atas (du) 1.6000 dan kurang dari $4-1.6000(4-\mathrm{du})$. Jika dilihat dari pengambilan keputusan, hasilnya termasuk dalam ketentuan $\mathrm{du}<\mathrm{d}<4-\mathrm{du}$, sehingga dapat disimpulkan bahwa $1.6000<$ $1.643<2.4000$ menerima H0 yang menyatakan bahwa tidak ada autokorelasi positif atau negatif berdasarkan tabel Durbin-Watson. Hal ini berarti tidak terjadi autokorelasi, sehingga model regresi layak digunakan.

\section{Analisis Regresi Linear Berganda}

Metode regresi linear berganda diterapkan untuk mengetahui arah hubungan antara dua atau lebih variabel independen dengan variabel dependen, apakah memiliki hubungan positif atau negatif. Model regresi linear berganda ini digunakan untuk membuktikan variabel Debt to Equity Ratio dan Net Profit Margin berpengaruh terhadap Perubahan laba. Untuk memperoleh gambaran 
umum sampel data penelitian, pada Tabel 4.6 disajikan hasil pengujian model regresi linear berganda untuk semua variabel yang digunakan.

Tabel. 8 Hasil Regresi Linear Berganda

\begin{tabular}{|l|l|l|l|}
\hline Variabel & $\begin{array}{l}\text { Koefisien } \\
\text { Regresi }\end{array}$ & $\mathbf{T}$ & Sig. \\
\hline DER & -121.411 & -15.149 & 0.000 \\
\hline NPM & 31.265 & 5.573 & 0.000 \\
\hline Konstanta & 48.935 & \\
\hline $\begin{array}{l}\text { Koefisien } \\
\text { Determinasi }\end{array}$ & 0.954 & \\
\hline Adjusted $\left(\mathrm{R}^{2}\right)$ & 0.952 & \\
\hline F Hitung & 386.904 & \\
\hline Signifikansi & 0.000 & \\
\hline
\end{tabular}

Tabel 9 Hasil Regresi Pengaruh Debt to Equity Ratio dan Net Profit Margin terhadap Perubahaan Laba pada Perusahaan sub sektor Konstruksi dan Bangunan yang terdaftar di Bursa Efek Indonesia

\begin{tabular}{|l|l|l|l|}
\hline \multicolumn{1}{|c|}{ Regresi } & \multicolumn{1}{|c|}{ Variabel } & \multicolumn{1}{c|}{ Sig. } & \multicolumn{1}{c|}{ Kesimpulan } \\
\hline Persamaan : & DER & 0.000 & H1 diterima \\
PL $=\alpha-\beta_{1} D E R+\beta_{2}$ NPM $+\mathrm{e}$ & NPM & 0.000 & H2 diterima \\
\hline
\end{tabular}

Dari data hasil regresi linear berganda seperti yang ditunjukkan pada Tabel 4.7 diatas, maka persamaan pengaruh Debt to Equity Ratio dan Net Profit Margin terhadap Perubahaan Laba pada Perusahaan sub sektor Konstruksi dan Bangunan adalah :

$\mathrm{PL}=\alpha-\beta 1 \mathrm{DER}+\beta 2 \mathrm{NPM}+\mathrm{e}$

$\mathrm{PL}=48.935-121.411 \mathrm{DER}+31.265 \mathrm{NPM}+\mathrm{e}$

Berdasarkan hasil yang diperoleh dalam persamaan regresi mengenai pengaruh Debt to Equity Ratio dan Net Profit Margin terhadap Perubahaan Laba, maka dapat diberikan interpretasi sebagai berikut :

a. Konstanta. Nilai konstanta sebesar 48.935 berarti bahwa jika tidak ada variabel independen yang terdiri dari DER dan NPM atau X=0, maka Perubahan Laba menunjukkan nilai sebesar 48.935 .

b. Koefisien Debt to Equity Ratio. Koefisien regresi X1 yaitu Debt to Equity Ratio sebesar 121.411 artinya jika variabel independen lain nilainya tetap, nilai Debt to Equity Ratio mengalami kenaikan 1\%, maka nilai Perubahan Laba mengalami penurunan sebesar -121.411. Koefisien bernilai negative artinya terjadi hubungan negatif antara nilai Debt to Equity Ratio dengan nilai Perubahaan Laba, semakin naik nilai Debt to Equity Ratio maka semakin turun nilai Perubahaan Laba.

c. Koefisien Net Profit Margin. Koefisien regresi X2 yaitu Net Profit Margin sebesar 31.625 artinya jika variabel independen lain nilainya tetap, nilai Net Profit Margin mengalami kenaikan 1\%, maka nilai Perubahaan Laba mengalami kenaikan sebesar 31.625. Koefisien bernilai positif artinya terjadi hubungan positif antara nilai Net Profit Margin dengan nilai Perubahan Laba, semakin naik nilai Net Profit Margin maka semakin naik nilai Perubahaan Laba. 


\section{Uji Kelayakan Model (Goodness of Fit)}

Ketepatan fungsi regresi sampel dalam menaksir nilai aktual dapat diukur dari Goodness of Fit. Secara statistik, setidaknya ini dapat diukur dari nilai koefisien determinasi, nilai statistik F dan nilai statistik t (Ghozali, 2013).

\section{a. Koefisien Determinasi}

Nilai koefisien korelasi (R) menunjukkan seberapa besar korelasi atau hubungan antara variabel-variabel independen dengan variabel dependen. Pada penelitian ini nilai koefisien determinasi adalah 0,954 yang berarti bahwa variable Debt to Equity Ratio (DER) dan Net Profit Margin (NPM) mempengaruhi Perubahaan Laba sebesar 95,4\%. Sisanya 4,6\% berasal dari variabel lain.

\section{b.Uji signifikansi parameter individual (uji t)}

Dasar Pengambilan Keputusan dalam uji hipotesis adalah sebagai berikut :

Jika probabilitasnya (nilai sig) $>0.05$ atau $-\mathrm{t}$ tabel $<\mathrm{t}$ hitung $<\mathrm{t}$ tabel maka $\mathrm{H} 0$ diterima.

Jika probabilitasnya (nilai sig) $<0.05$ atau $\mathrm{t}$ hitung $<-\mathrm{t}$ tabel atau $\mathrm{t}$ hitung $>\mathrm{t}$ tabel maka $\mathrm{H} 0$ ditolak.

1) Uji Hipotesis H1: Debt to Equity Ratio berpengaruh terhadap Perubahaan Laba. Hasil uji t variabel DER sebesar dengan nilai thitung $-15.149>$ ttabel 2.026 dengan sig sebesar 0.000 yang berada dibawah 0.05. Dengan demikian hipotesis pertama (H1) diterima, ini berarti DER berpengaruh negatif signifikan secara statistik terhadap Perubahaan Laba.

2) Uji Hipotesis H2: Net Profit Margin berpengaruh terhadap Perubahaan Laba. Hasil uji t variabel NPM sebesar dengan thitung $5.753>$ ttabel 2.026 dengan sig sebesar 0.000 yang berada dibawah 0.05 . Dengan demikian hipotesis kedua (H2) diterima, ini berarti NPM berpengaruh signifikan secara statistik terhadap Perubahaan Laba.

\section{c. Uji signifikansi simultan F ( uji f )}

Uji Statistik F pada dasarnya menunjukkan apakah semua variabel independen yang dimasukkan dalam model mempunyai pengaruh secara bersama-sama terhadap variabel dependen. Hasil uji F dari pengujian statistik pada Tabel 4.8 diperoleh nilai Fhitung sebesar $396.904>$ Ftabel 3.25 dan signifikansi sebesar $0.000<0.05$ maka dapat disimpulkan bahwa hipotesis yang menyatakan ada pengaruh Debt to Equity Ratio dan Net Profit Margin berpengaruh secara simultan terhadap Perubahaan Laba. diterima.

Tabel 10 ANOVA ${ }^{\mathrm{a}}$

\begin{tabular}{|l|l|l|l|l|l|}
\hline Model & Sum of Squares & df & Mean Square & F & Sig. \\
\hline Regression & 28644723.524 & 2 & 14322361.762 & 386.904 & $.000^{\mathrm{b}}$ \\
Residual & 1369659.976 & 37 & 37017.837 & & \\
Total & 30014383.500 & 39 & & & \\
\hline
\end{tabular}

a. Dependent Variable: PL

b. Predictors: (Constant), NPM, DER

\section{PEMBAHASAN PENELITIAN}

\section{Pengaruh Debt to Equity Ratio terhadap Perubahan Laba}

Perusahaan sub sektor konstruksi dan bangunan yang menggunakan sumber dana hutang pada bank (kreditor) akan timbul beban bunga dan beban beban lainnya, hal tersebut akan menyebabkan perusahaan akan membayar hutang pada bank dan membayar beban bunga yang ditanggung oleh perusahaan, sehingga laba yang diperoleh akan mengalami penurunan laba pada perusahaan. Hal ini menunjukan bahwa adanya pengaruh negatif Debt to Equity Ratio terhadap Perubahaan Laba. Perusahaan konstruksi dan pembangunan yang memperoleh nilai pengembalian investasinya kecil lebih memanfaatkan utang dengan relatif besar.

Dan dari hasil perhitungan uji parsial diperoleh bahwa variabel Debt to Equity Ratio sebesar dengan nilai thitung $-15.149>$ ttabel 2.026 dengan sig sebesar 0.000 yang berada dibawah 0.05 . 
Diketahui bahwa sumbangan efektif (SE) variabel Debt to Equity Ratio terhadap Perubahan Laba adalah sebesar 54,3\% dan sumbangan relatif (SR) sebesar 57\%. Dengan demikian hipotesis pertama (H1) diterima, ini berarti Debt to Equity Ratio berpengaruh negatif signifikan secara statistik terhadap Perubahaan Laba.

Hasil penelitian ini sejalan dengan penelitian Cyntia dan Evelin (2016), Mas'ulah dan Budiyanto (2016), yang menyatakan bahwa DER berpengaruh signifikan terhadap perubahaan laba perusahaan. Dan hasil penelitian ini tidak sejalan dengan penelitian Dina Rohmatin (2017) yang menyatakan bahwa DER secara parsial tidak berpengaruh signifikan terhadap perubahan laba.

\section{Pengaruh Net Profit Margin terhadap Perubahan Laba}

Dari hasil uji t variabel Net Profit Margin sebesar dengan thitung $5.753>$ ttabel 2.026 dengan sig sebesar 0.000 yang berada diatas 0.05. Dan diketahui bahwa sumbangan efektif (SE) variabel Net Profit Margin terhadap Perubahan Laba sebesar $41.1 \%$ dan sumbangan relatif (SR) sebesar 43\%. Dengan demikian hipotesis kedua (H2) diterima, ini berarti Net Profit Margin berpengaruh signifikan secara statistik terhadap Perubahaan Laba. Hal ini sejalan dengan penelitian Weily Riduan dan Budiharjo (2019) CR, DER, dan NPM berpengaruh secara simultan untuk mendapatkan perubahaan. Berdasarkan pengujian variabel secara individu didapatkan bahwa CR dan DER tidak memiliki pengaruh signifikan terhadap perubahaan laba, sedangkan NPM memiliki pengaruh signifikan terhadap perubahaan laba.

Hasil penelitian ini mengidentifikasi bahwa meningkat atau menurunnya Net Profit Margin selama periode penelitian mempengaruhi kenaikan perubahaan laba. Hal itu bisa saja terjadi dikarenakan kemampuan NPM pengaruhnya terhadap perubahaan laba karena rasio ini berhubungan dengan efisiensi perusahaan sub sektor konstruksi dan bangunan dalam memproduksi, administrasi, pemasaran, pendanaan, dan penentuan harga. Pengaruh yang positif memberikan arti bahwa setiap kenaikan NPM dapat menaikkan perubahaan laba. Rasio ini bertambah disebabkan oleh bertambahnya penjualan lebih besar dari bertambahnya biaya usaha maka akan mengakibatkan bertambahnya laba di masa yang akan datang.

Hasil penelitian ini sejalan dengan penelitian Riduan N dan Budiharjo (2019), Mas'ulah dan Budiyanto (2016), Chyntia dan Evelin (2016), Catur Setia Nugraha (2017), yang menyatakan bahwa NPM memiliki pengaruh signifikan dan memiliki hubungan positif terhadap perubahaan laba. Dan hasil penelitian ini tidak sejalan dengan penelitian Arlinia dan Subekti (2017) yang menyatakan bahwa NPM secara parsial tidak berpengaruh terhadap perubahan laba.

\section{Pengaruh Debt to Equity Ratio dan Net Profit Margin terhadap Perubahan Laba}

Debt to Equity Ratio dan Net Profit Margin memiliki pengaruh yang signifikan secara simultan terhadap Perubahaan Laba. Berdasarkan uji simultan atau uji F, menunjukkan bahwa nilai Fhitung sebesar $386.904>$ Ftabel 3.25 dan signifikansi sebesar $0.000<0.05$ maka dapat disimpulkan bahwa hipotesis yang menyatakan ada pengaruh Debt to Equity Ratio dan Net Profit Margin berpengaruh secara simultan terhadap Perubahaan Laba diterima.

Koefisien determinasi memiliki nilai 0.954 atau 95.4\% menunjukkan bahwa Debt to Equity Ratio dan Net Profit Margin berpengaruh terhadap Perubahaan Laba sebesar 95.2\%, sedangkan sisanya 4.6\% dijelaskan variabel lain seperti Current Ratio (CR), Total Asset Turn Over (TATO), Gross Profit Margin (GPM) yang tidak dijelaskan dalam penelitian ini.

Dari hasil yang didapat maka semakin tingginya Debt to Equity Ratio maka perubahaan laba yang akan menurun. Sehingga semakin berkurangnya kewajiban hutang yang dimiliki perusahaan, jika Debt to Equity semakin menurun maka semakin naik Net Profit Margin dan Perubahaan Laba nya juga akan terus meningkat, sehingga perusahaan akan mendapat keuntungan yang lebih tinggi dikarenakan tidak adanya kewajiban perusahaan terhadap pihak eksternal. Hal ini akan menambahkan minat investor dalam menanamkan dananya di perusahaan. 


\section{KESIMPULAN DAN SARAN}

\section{Kesimpulan}

Berdasarkan hasil penelitian ini maka dapat ditarik kesimpulan sebagai berikut :

a. Dan dari hasil perhitungan uji parsial diperoleh bahwa variabel Debt to Equity Ratio sebesar dengan nilai thitung $-15.149>$ ttabel 2.026 dengan sig sebesar 0.000 yang berada dibawah 0.05. Diketahui bahwa sumbangan efektif (SE) variabel DER terhadap Perubahan Laba adalah sebesar 54,3\% dan sumbangan relatif (SR) sebesar 57\%. Dengan demikian hipotesis pertama (H1) diterima, ini berarti Debt to Equity Ratio berpengaruh negatif signifikan secara parsial terhadap Perubahaan Laba.

b. Dari hasil uji t variabel Net Profit Margin sebesar dengan thitung $5.753>$ ttabel 2.026 dengan sig sebesar 0.000 yang berada diatas 0.05. Dengan diketahui bahwa sumbangan efektif (SE) variabel NPM terhadap Perubahan Laba sebesar $41.1 \%$ dan sumbangan relatif (SR) sebesar 43\%. Dengan demikian hipotesis kedua (H2) diterima, ini berarti Net Profit Margin berpengaruh signifikan secara parsial terhadap Perubahaan Laba.

c. Dari hasil uji simultan atau uji F, menunjukkan bahwa nilai Fhitung sebesar $396.904>$ Ftabel 3.25 dan signifikansi sebesar $0.000<0.05$ maka dapat disimpulkan bahwa hipotesis yang menyatakan ada pengaruh Debt to Equity Ratio dan Net Profit Margin berpengaruh secara simultan terhadap Perubahaan Laba diterima. Dari hasil koefisien determinasi memiliki nilai 0.954 menunjukkan bahwa DER dan NPM berpengaruh terhadap Perubahaan Laba sebesar 95.4\%, Hal itu terjadi dikarenakan Perubahan Laba pada perusahaan konstruksi selalu berfluktuatif, sedangkan sisanya $4.6 \%$ dijelaskan variabel lain seperti Current Ratio, (CR), Total Assets Turn Over (TATO), dan Gross Profit Margin (GPM)

\section{Saran}

Penelitian ini masih membutuhkan beberapa item perbaikan untuk dilakukan pada penelitianpenelitian selanjutnya yang memiliki keterkaitan dengan objek penelitian yang sejenis sehingga dapat menjadikan penelitian ini lebih baik.

a. Bagi peneliti selanjutnya diharapkan dapat meneliti dengan variabel-variabel lain diluar variabel ini agar memperoleh hasil yang lebih bervariatif yang dapat menggambarkan hal-hal apa saja yang dapet berpengaruh terhadap Perubahan Laba dan untuk memperluas cakupan peneliti tentang pengaruh rasio keuangan terhadap kemampuan perusahaan subsektor konstruksi dalam memperoleh keuntungan secara keseluruhan dengan menggunakan rasio-rasio lain selain rasio yang dipakai pada penelitian ini seperti Total Asset Turn Over (TATO), Current Ratio (CR), Gross Profit Margin (GPM).

b. Bagi peneliti selanjutnya dapat memperpanjang periode penelitian agar dapat diperoleh hasil penelitian yang lebih baik dan akurat serta menambah jumlah sampel yang diteliti dan populasi penelitian tidak hanya dikhususkan pada perusahaan sub konstruksi, tetapi dapat diperluas pada perusahaan lainnya yang terdaftar di Bursa Efek Indonesia.

c. Bagi pihak perusahaan diharapkan selalu menjaga tingkat laba. Dengan menstabilkan dan menjaga rasio Debt To Equity Ratio (DER) diposisi ideal serta memperhatikan kualitas laba yang disalurkan untuk menghindari terjadinya perubahan laba sehingga dapat memperoleh keuntungan dari laba yang diterima dari investor.

\section{DAFTAR PUSTAKA}

\section{Sumber Buku :}

Agoes, S. d. (2013). Akuntansi Perpajakan Edisi 3. Jakarta: Salemba Empat.

Buchari, A. (2016). Manajemen Pemasaran dan Pemasaran Jasa. Bandung : CV. Alfabeta.

Darsono dan Ashari. (2010). Pedoman Praktis Memahami Laporan Keuangan. Yogyakarta: Penerbit Andi. 
Dewi Utari, A. P. (2014). Manajemen 12345 Keuangan Edisi Revisi. Jakarta : Mitra Wacana Media.

Ghozali, Imam. (2016). Aplikasi Analisis Multivariete Dengan Program IBM SPSS 23 (Edisi 8). Cetakan ke VIII. Semarang : Badan Penerbit Universitas Diponegoro.

Hanafi, Mamduh M dan Abdul Halim. (2016). Analisis Laporan Keuangan. Edisi Kelima. Yogyakarta: UPP STIM YKPN.

Harahap, Sofyan Syafri. (2015). Analisis Kritis atas Laporan Keuangan. Edisi 1-10 . Jakarta: Rajawali Pers.

Harrison, W. T. (2012). Akuntansi Keuangan: International Financial Reporting Standars. Jakarta: Penerjemah Gina Gania.Erlangga .

Hery. (2015). Analisis Laporan Keuangan. Edisi 1. Yogyakarta: Center For Academic Publishing Services.

Kasmir. (2010). Pengantar Manajemen Keuangan. Jakarta: Kencana Prenada Media Group.

Kasmir. (2012). Analisis Laporan Keuangan. Jakarta : PT. Raja Grafindo Persada.

Kasmir. (2013). Analisis Laporan Keuangan. Jakarta: Rajawali Pers .

Kasmir. (2014). Analisis Laporan Keuangan, Edisi Pertama, Cetakan Ketujuh. Jakarta: PT. Rajagrafindo Persada.

Kasmir. (2017). Analisis Laporan Keuangan. Jakarta: Raja Grafindo Persada.

M Reeve James, d. (2013). Pengantar Akuntansi. Jakarta: Buku I Salemba Empat.

Madura, jeff. (2010). financial institution and market nineth edition. canada south: western cengange learning thomson south western.

Martani, D. (2012). Akuntansi Keuangan Menengah Berbasis PSAK. Jakarta: Salemba Empat.

Mulyadi. (2015). Akuntansi Biaya Edisi 5. Yogyakarta : Sekolah Tinggi Ilmu Manajemen YKPN.

Murhadi, Werner R. (2015). Analisis Laporan Keuangan, Proyeksi dan Valuasi Saham. Jakarta: Salemba Empat.

Nelson Lam, Peter Lau. (2014). Akuntansi Keuangan (Intermediate Financial Reporting). Jakarta: Buku 1, Edisi 2. Salemba Empat.

Sadono, S. (2010). Makro ekonomi. Teori Pengantar Edisi Ketiga. Jakarta: PT. Raja Grasindo Perseda.

Samryn, L. (2012). Akuntansi Manajemen Informasi Biaya untuk Mengendalikan Aktivitas Operasi dan Investasi. Edisi Pertama. Jakarta: Kencana Prenada Media Group.

Sjahrial, D. (2012). Pengantar Manajemen Keuangan. Jakarta: Mitra Wacana Media.

Subramanyam dan John J. Wild. (2012). Analisis Laporan Keuangan. Jakarta: Salemba Empat.

Subramanyam. K. R dan John J. Wild. (2014). Analisi Laporan Keuangan. Penerjemah Dewi Y. Jakarta: Salemba Empat.

Sugiyono. (2015). Metode Penelitian Kombinasi (Mix Methods). Bandung: Alfabeta.

Sugiyono. (2016). Metode Penelitian Kuantitatif, Kualitatif dan R\&D. Bandung: PT Alfabet.

Sugiyono. (2017). Metode Penelitian Kuantitatif, Kualitatif, dan R\&D. Bandung : Alfabeta, CV.

Tunggal, A. W. (2010). Teori dan Praktek Auditing. Jakarta: Harvarindo. 
Sumber Jurnal :

Arlinia dan Subekti. (2017). Pengaruh Rasio Keuangan Terhadap Perubahan Laba Pada Perindustrian Perikanan. Jurnal Online Insan Akuntan, Vol.2, No.2 Desember 2017, 189 - 202 E-ISSN: 2528-0163, 202.

Mas'ulah dan Budiyanto. (2016). Pengaruh Current Ratio, Debt To Equity Ratio, Total Assets Turnover, Net Profit Margin, Terhadap Perubahan Laba Pada Perusahaan. Jurnal Ilmu dan Riset Manajemen : Volume 5, Nomor 1, Januari 2016 ISSN : 2461-0593, 17.

Nugraha. (2017). Analisis Pengaruh Debt To Equity Ratio (Der), Total Assets Turnover (Tato), Dan Net Profit Margin (Npm) Terhadap Perubahan Laba Pada Perusahaan Manufaktur Sektor Barang Konsumsi Yang Terdaftar Di Bursa Efek Indonesia Pada Periode 2013-2015 . SimkiEconomic Vol. 01 No. 10 Tahun 2017 ISSN : BBBB-BBBB, 12.

Riduan dan Budiharjo. (2019). Pengaruh Cr, Der Dan Npm Terhadap Perubahan Laba Pada Perusahaan Jasa Perhotelan . Vol 14 (1) 2019, 15-32, 32.

Riduan dan Budiharjo. (2019). Pengaruh Cr, Der Dan Npm Terhadap Perubahan Laba Pada Perusahaan Jasa Perhotelan . Vol 14 (1) 2019, 15-32 http://journal.unj/unj/index.php/wahanaakuntansi ISSN 2302-1810 (online) DOI: doi.org/10.21009/wahana-akuntansi/14.1.02, 32.

Rohmatin. (2017). Pengaruh Debt To Equity Ratio (Der), Total Asset Turnover (Tato), Gross Profit Margin (Gpm), Return On Equity (Roe) Terhadap Perubahan Laba Pada Perusahaan Properti Dan Real Estate Yang Listing Di Bursa Efek Indonesia Tahun 2013-2015 . Simki-Economic Vol. 01 No. 07 Tahun 2017 ISSN : BBBB-BBBB, 4. 